\title{
Elaboration and characterization of mullite-anorthite-albite porous ceramics prepared from Algerian kaolin
}

\author{
(Elaboração e caracterização de cerâmicas porosas de \\ mulita-anortita-albita preparadas a partir de caulim argelino)
}

\author{
F. Rouabhia, A. Nemamcha*, H. Moumeni \\ Group Surfaces, Interfaces and Nanostructures, Laboratory of Industrial Analysis and Materials Engineering, \\ Department of Chemical Engineering, Faculty of Sciences and Technology, University 8 Mai 1945, \\ Guelma 24000, Algeria \\ fatirouabhi@yahoo.fr,arnemamcha_dz@yahoo.fr,hmoumeni@yahoo.fr
}

\begin{abstract}
Mullite-anorthite-albite porous ceramic materials were successfully prepared by a solid-state reaction between kaolin clay and two different additives $\left(\mathrm{CaCO}_{3}\right.$ and $\left.\mathrm{Na}_{2} \mathrm{CO}_{3}\right)$. The starting raw material was characterized by $\mathrm{X}$-ray fluorescence, $\mathrm{X}$-ray diffraction (XRD) and dynamic light scattering techniques. The effect of $\mathrm{CaCO}_{3}$ and $\mathrm{Na}_{2} \mathrm{CO}_{3}$ concentration (10 to $\left.70 \mathrm{wt} \%\right)$ on structure, morphology and thermal properties of the obtained ceramics was investigated by XRD, scanning electron microscopy and differential scanning calorimetry (DSC) techniques. The XRD patterns showed that mullite $\left(3 \mathrm{Al}_{2} \mathrm{O}_{3} \cdot 2 \mathrm{SiO}_{2}\right)$, anorthite $\left(\mathrm{CaO} \cdot \mathrm{Al}_{2} \mathrm{O}_{3} \cdot 2 \mathrm{SiO}_{2}\right)$ and albite $\left(\mathrm{Na}_{2} \mathrm{O} \cdot \mathrm{Al}_{2} \mathrm{O}_{3} \cdot 6 \mathrm{SiO}_{2}\right)$ were the main crystalline phases present in the materials. The morphology investigation revealed the porous texture of obtained ceramics characterized by the presence of sponge-like structure mainly due to the additive decomposition at high temperatures. The DSC results confirm the presence of four temperature regions related to the kaolin thermal transformations and the formation of minerals. The temperature and enthalpy of mineral formation are additive concentration dependent. As a result, the optimal content of additives which allowed the coexistence of the three phases, a spongelike morphology, and high porosity without cracks corresponded to $15 \mathrm{wt} \% \mathrm{CaCO}_{3}, 15 \mathrm{wt} \% \mathrm{Na}_{2} \mathrm{CO}_{3}$, and $70 \mathrm{wt} \% \mathrm{kaolin}$.
\end{abstract}

Keywords: clay materials, kaolin, porous ceramics, structure, morphology, thermal analysis.

\section{Resumo}

Materiais cerâmicos porosos de mulita-anortita-albita foram preparados com sucesso por reação no estado sólido entre argila caulinitica e dois aditivos ( $\mathrm{CaCO}_{3}$ e $\left.\mathrm{Na}_{2} \mathrm{CO}_{3}\right)$. A matéria-prima foi caracterizada por técnicas de fluorescência de raios $X$, difração de raios $\mathrm{X}(\mathrm{DRX})$ e dispersão de luz dinâmica. O efeito da concentração de $\mathrm{CaCO}_{3}$ e $\mathrm{Na}_{2} \mathrm{CO}_{3}(10 \mathrm{a} 70 \% \mathrm{em}$ massa) na estrutura, morfologia e propriedades térmicas das cerâmicas obtidas foi investigado por técnicas de DRX, microscopia eletrônica de varredura e calorimetria de varredura diferencial (DSC). A análise de DRX mostrou que mulita $\left(3 \mathrm{Al}_{2} \mathrm{O}_{3} .2 \mathrm{SiO}_{2}\right)$, anortita $\left(\mathrm{CaO} . \mathrm{Al}_{2} \mathrm{O}_{3} .2 \mathrm{SiO}_{2}\right)$ e albita $\left(\mathrm{Na}_{2} \mathrm{O}_{\mathrm{Al}} \mathrm{O}_{3} .6 \mathrm{SiO}\right.$ ) foram as principais fases cristalinas presentes nos materiais. A investigação da morfologia revelou textura porosa das cerâmicas obtidas, caracterizadas pela presença de estrutura tipo esponja principalmente devido à decomposição dos aditivos em altas temperaturas. Os resultados de DSC confirmaram a presença de quatro regiões de temperatura relacionadas às transformações térmicas do caulim e à formação de minerais. A temperatura e a entalpia da formação de minerais são dependentes da concentração de aditivos. Como resultado, o conteúdo ótimo de aditivos que permitiu a coexistência das três fases, morfologia na forma de esponja e alta porosidade sem trincas correspondeu a $15 \%$ CaCO ${ }_{3}$, $15 \%$ $\mathrm{Na}_{2} \mathrm{CO}_{3}$ e $70 \%$ caulim.

Palavras-chave: materiais de argila, caulim, cerâmica porosa, estrutura, morfologia, análise térmica.

\section{INTRODUCTION}

During the last decade, many studies have been devoted to the development and production of new technical ceramics, using available and low-cost natural raw materials. Ceramic materials prepared from natural raw clays are currently used as biomaterials [1], catalyst supports [2], gases filters [3], sensors [4], membrane reactors [5], and water treatment systems [6]. Clays based ceramics are aluminosilicates with layered structure where every layer is composed by two, three or four sheets. The sheet is formed by siliceous tetrahedrons and by aluminum octahedrons. The center of tetrahedrons and octahedrons contains metal cations and their apices are occupied by oxygen atoms or hydroxyl groups $[7,8]$. The final composition of raw clays depends on the geological transformations of the parent rocks. The most important group of clays minerals is the doublesheet phyllosilicate kaolinite. The kaolinite (hydrated aluminosilicate, $\mathrm{Al}_{2} \mathrm{Si}_{2} \mathrm{O}_{5}(\mathrm{OH})_{4}$ ) is composed by stacked sheets of tetrahedral silica layer $\left[\mathrm{Si}_{2} \mathrm{O}_{5}\right]^{2-}$ and an alumina octahedral layer $\left[\mathrm{Al}_{2}(\mathrm{OH})_{4}\right]^{2+}[9]$. The heat treatment at high temperatures of kaolinite-clays leads to the formation 
of various minerals based on alumina-silica system such as mullite, gehlenite, anorthite and albite [10,11].

Mullite (aluminum silicate, $3 \mathrm{Al}_{2} \mathrm{O}_{3} \cdot 2 \mathrm{SiO}_{2}$ ) is one of the most important component of the conventional and advanced ceramics. This mineral is usually obtained by the transformation of kaolinite to mullite with orthorhombic structure. The crystal structure of mullite is closely related to that of sillimanite, characterized by a backbone constituted of parallel chains of connected octahedra $\left[\mathrm{AlO}_{6}\right]^{6-}$ running parallel to crystallographic c axis. These very stiff chains are cross-linked by tetrahedral chains of $\left[\mathrm{AlO}_{4}\right]^{4-}$ and $\left[\mathrm{SiO}_{4}\right]^{4-}$ tetrahedra with bridging oxygen atoms [12]. The anorthite (calcium aluminum silicate, $\mathrm{CaO} \cdot \mathrm{Al}_{2} \mathrm{O}_{3} \cdot 2 \mathrm{SiO}_{2}$ ) structure consists of the framework of four membered rings of $\left[\mathrm{SiO}_{4}\right]^{4-}$ and $\left[\mathrm{AlO}_{4}\right]^{4-}$ tetrahedra, where $\mathrm{Ca}^{2+}$ ions occupy the cavity and compensate the negative charge of aluminosilicate framework [10]. For more details, anorthite structure is characterized by an alternate of $\mathrm{Si}$ and Al tetrahedra, each oxygen atom has one $\mathrm{Si}$ atom and one $\mathrm{Al}$ atom neighbor without $\mathrm{Si} / \mathrm{Al}$ disorder. The number of calcium atoms present near the $\mathrm{O}$ atoms regulates the $\mathrm{Si}-\mathrm{O}$ and $\mathrm{Al}-\mathrm{O}$ bound lengths [13]. The anorthite crystallizes in triclinic system with theoretical density of about $2.75 \mathrm{~g} / \mathrm{cm}^{3}$ [14]. Usually, anorthite is prepared by devitrification of glass, with addition of a nucleation agent, or from kaolin and calcium carbonate mixtures at high temperature. The albite (sodium aluminum silicate, $\mathrm{Na}_{2} \mathrm{O} \cdot \mathrm{Al}_{2} \mathrm{O}_{3} \cdot 6 \mathrm{SiO}_{2}$ ) mineral presents two different crystalline phases at low and high temperatures according to a triclinic system. The examination of their structures shows that the aluminum atoms and siliceous atoms are distributed according four non-equivalent tetrahedra. This arrangement is highly ordered in low albite, the first site Si contains nearly all the $\mathrm{Al}$ atoms while in high albite the $\mathrm{Al}$ and $\mathrm{Si}$ atoms are randomly distributed throughout the four tetrahedral sites. A marked anisotropy of sodium atoms in both phases depends on the formation temperature [15]. The albite mineral is usually white with shades of blue, yellow, orange and brown formed by vitreous and transparent crystals. The albite grains have a tabular and platy morphology. The typical crystal has a nearly rectangular or square cross-section with slightly slanted dome and pinacoid terminations. Albite is a common constituent of granitic and syenite rocks [16].

Many works [17-19] have proved that porous mulliteceramics, obtained from clays, are useful refractory materials for water treatment, high-temperature applications due to their high porosity, low thermal expansion coefficient, high creep resistance and corrosion resistance. Indeed, low cost alumina-mullite composites have been produced in [20] via reactive sintering of kaolinite clay and aluminum hydroxide with flexural strength reaching $70 \mathrm{MPa}$ for a sintering at $1600{ }^{\circ} \mathrm{C}$. Recently, a pure-mullite based ceramics have been prepared by reactive sintering method from a mixture of kaolin and mica-rich kaolin waste [21]. In addition, high strength mullite whisker network reinforced ceramic materials were successfully achieved by firing a bauxite-kaolin-coal fly ash mixture with addition of varying mixtures of feldspar-talcpyrolusite [22]. Other studies [23, 24] have confirmed that the presence of anorthite increases the strength and chemical stability of the material and improves its physical properties such as low thermal expansion coefficient, high thermal shock resistance, and low dielectric constant. Actually, porous anorthite ceramics with high compressive strength are obtained from mixtures of paper processing residues and clays [25]. Anorthite based ceramics with an important dielectric resistance were also prepared from kaolin DD2 and calcite [26]. Moreover, it has been found that the albite promotes the chemical properties of albite-ceramics [27, 28]. Furthermore, the use of the diopside-albite system permits obtaining glass-ceramics with high mechanical properties [29]. On the other hand, albite and anorthite compounds are very useful for microwave dielectric application [30]. In order to achieve all these important properties, the present work reports the synthesis and characterization of porous ceramics containing simultaneously mullite, anorthite and albite phases prepared from kaolin clay (cheap raw materials and easily accessible in Algeria) and different amounts of calcite, $\mathrm{CaCO}_{3}$, and sodium carbonate, $\mathrm{Na}_{2} \mathrm{CO}_{3}$, as additives. The influence of additive content on ceramics properties (structure, morphology, thermal transformations) is investigated.

\section{MATERIALS AND METHODS}

Ceramic samples (S0, S10, S30, S50 and S70) were prepared by a mixture of kaolin clay $\left(\mathrm{Al}_{2} \mathrm{O}_{3} \cdot 2 \mathrm{SiO}_{2} \cdot 2 \mathrm{H}_{2} \mathrm{O}\right.$ $2 \mathrm{H}_{2} \mathrm{O}$ ) from Guelma region (Algeria) and different proportions of calcite, $\mathrm{CaCO}_{3}$, and sodium carbonate, $\mathrm{Na}_{2} \mathrm{CO}_{3}$, as shown in Table I, according to the main steps resumed in Fig. 1. In order to obtain homogeneous mixture of very fine particles and improve the solid-state reaction, the mixtures were dried at $100{ }^{\circ} \mathrm{C}$ for $1 \mathrm{~h}$ and milled using a Pulverisette P4 ball mill with an agate vial during $1 \mathrm{~h}$ at $400 \mathrm{rpm}$. The obtained powders were classified at $50 \mu \mathrm{m}$ (particle size) using an appropriate molecular vibrating sieve. After milling, small samples $\left(3 \times 1 \times 1 \mathrm{~cm}^{3}\right)$ were prepared by a progressive addition of water to allow the shaping. The samples were dried at $120{ }^{\circ} \mathrm{C}$ for $4 \mathrm{~h}$ and heat treated at $1200{ }^{\circ} \mathrm{C}$ in an electric furnace during $6 \mathrm{~h}$ with a heating rate of $10^{\circ} \mathrm{C} / \mathrm{min}$.

The chemical composition of kaolin was determined using X-ray fluorescence (XRF) technique. The particle size distribution of kaolin clay was performed with a Malvern laser particle analyzer (Hydro-2000MU) on dispersed particles in deionized water. The crystalline phases formation was followed by X-ray diffraction (XRD) technique using a D8 Advance Bruker AXS diffractometer equipped with

Table I - Sample compositions (wt $\%$ ).

[Tabela I - Composições (\% em massa) das amostras.]

\begin{tabular}{cccccc}
\hline Sample & S0 & S10 & S30 & S50 & S70 \\
\hline Kaolin & 100 & 90 & 70 & 50 & 30 \\
$\mathrm{Na}_{2} \mathrm{CO}_{3}$ & 0 & 5 & 15 & 25 & 35 \\
$\mathrm{CaCO}_{3}$ & 0 & 5 & 15 & 25 & 35 \\
\hline
\end{tabular}




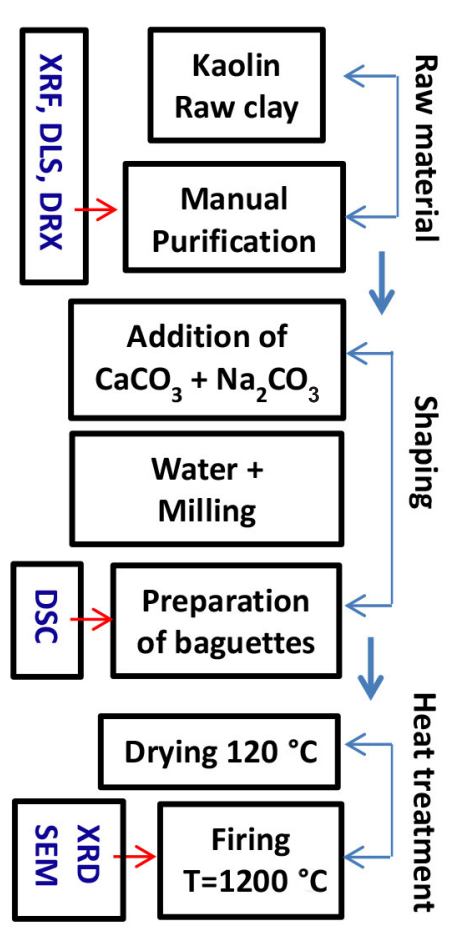

Figure 1: Experimental procedure of sample preparation.

[Figura 1: Procedimento experimental de preparação das amostras.]

a CuK $\alpha$ radiation $(\lambda=1.54056 \AA, 40 \mathrm{kV}$ and $40 \mathrm{~mA})$ and a monochromator in the angular range $5^{\circ}-80^{\circ}$ with a step size $\Delta 2 \theta=0.02^{\circ}$. Differential scanning calorimetry (DSC) was performed in a DSC-LabSys-Evo under nitrogen atmosphere at a heating rate of $10^{\circ} \mathrm{C} / \mathrm{min}$ in a temperature range of $25-1500^{\circ} \mathrm{C}$. The sample morphology was observed by a scanning electron microscope (SEM, Hitachi S-2500). The bulk density and apparent porosity were estimated by Archimedes' method using deionized water.

\section{RESULTS AND DISCUSSION}

Characterization of starting raw materials: the chemical composition of natural clay (Table II) showed that the main components were $\mathrm{SiO}_{2}$ (48.16 wt\%) and $\mathrm{Al}_{2} \mathrm{O}_{3}(38.15 \mathrm{wt} \%)$ which favors the formation of aluminosilicate compounds. In addition, the clay contained $1.17 \%$ of $\mathrm{Fe}_{2} \mathrm{O}_{3}, 0.28 \%$ of $\mathrm{CaO}$, and $0.12 \%$ of $\mathrm{Na}_{2} \mathrm{O}$ which were considered as impurities. The large proportions of alumina and silica indicated the predominance of kaolinite mineral in this clay. The $\mathrm{SiO}_{2} / \mathrm{Al}_{2} \mathrm{O}_{3}$ ratio was about 1.26 which confirmed the high plasticity of the kaolin. The analysis of the XRD pattern of the raw material (Fig. 2) showed that the kaolin

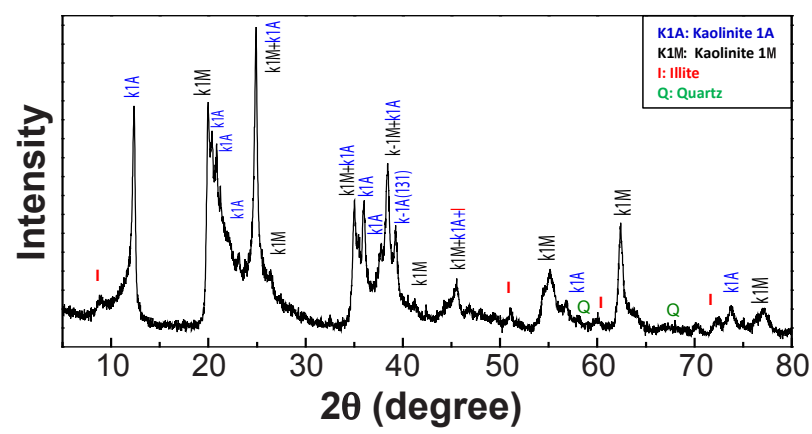

Figure 2: X-ray diffraction pattern of starting clay. [Figura 2: Difratograma de raios $X$ da argila inicial.]

was formed essentially by a mixture of two kaolinite crystalline phases identified as kaolinite 1A (JCPDS 140164) and kaolinite 1M (JCPDS 29-1488). Traces of illite and free quartz were also detected.

The particles size distribution of kaolin is shown in Fig. 3. The curve exhibits a likely heterogeneous large size distribution with a multimodal behavior revealing the presence of three particle populations: $10 \%$ of particles $\left(\mathrm{d}_{10}\right)$ have a diameter less than $5 \mu \mathrm{m}$ with a maximum distribution centered at $3.42 \mu \mathrm{m} ; 50 \%$ of particles $\left(\mathrm{d}_{50}\right)$ which have a medium diameter less than $50 \mu \mathrm{m}$ present a maximum distribution around $19.5 \mu \mathrm{m}$; and the clay also contained big particles $\left(\mathrm{d}_{90}\right)$ with a size distribution centered at $60.45 \mu \mathrm{m}$.

Structural investigation of ceramics: Fig. 4 shows the evolution of XRD patterns of the studied materials as a function of additive concentration. The XRD pattern of sample without additives (S0) exhibited the mullite diffraction peaks as a major component (Fig. 4a). High

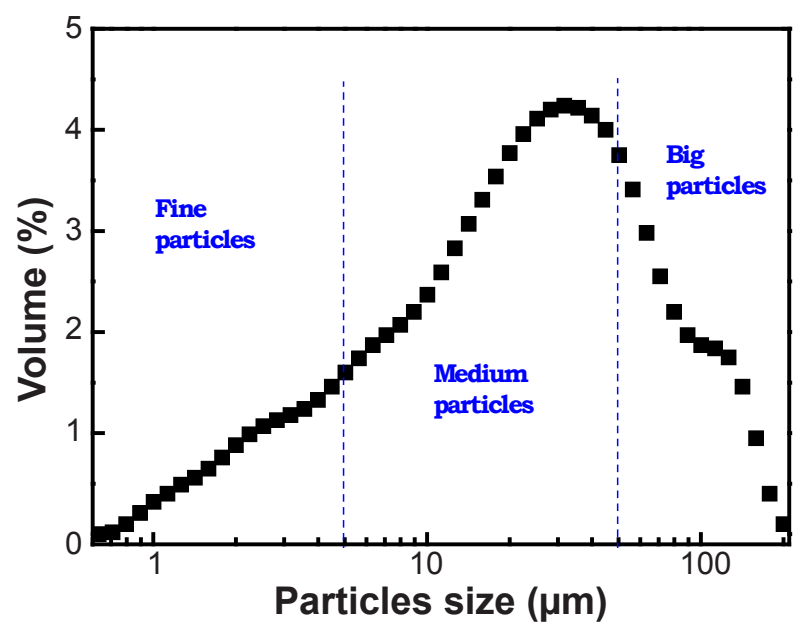

Figure 3: Particles size distribution curve of kaolin clay. [Figura 3: Curva de distribuição de tamanho de partículas da argila caulinítica.]

Table II - Chemical composition (wt \%) of raw material (clay).

[Tabela II - Composição química (\% em massa) da matéria-prima (argila).]

\begin{tabular}{cccccccccc}
\hline $\mathrm{SiO}_{2}$ & $\mathrm{Al}_{2} \mathrm{O}_{3}$ & $\mathrm{Fe}_{2} \mathrm{O}_{3}$ & $\mathrm{CaO}$ & $\mathrm{MgO}$ & $\mathrm{SO}_{3}$ & $\mathrm{~K}_{2} \mathrm{O}$ & $\mathrm{Na}_{2} \mathrm{O}$ & $\mathrm{P}_{2} \mathrm{O}_{5}$ & $\mathrm{TiO}_{2}$ \\
\hline 48.16 & 38.15 & 1.17 & 0.28 & 0.18 & 1.51 & 0.19 & 0.12 & 0.03 & 0.05 \\
\hline
\end{tabular}


intensity mullite peaks were detected at $26.20^{\circ}, 35.24^{\circ}$, $40.84^{\circ}$ and $60.8^{\circ}$ attributed to (210), (111), (121) and (331) diffraction planes, respectively (JCPDS 15-0776). The mullite diffraction peaks were superimposed to a broad halo typical of a highly disordered amorphous phase. Three weak peaks corresponding to the cristobalite phase detected at $22.15^{\circ}, 66.48^{\circ}$ and $70.72^{\circ}$ were attributed to (101), (223) and (321) diffraction planes, respectively (JCPDS 04-0379). Alves et al. [31] have expected the presence of cristobalite in the kaolin based ceramics due to the transformation of excess amount of silica and the quartz at high temperature. For $\mathrm{S} 10$, one observes the appearance of new peaks at $28.04^{\circ}$, $31.44^{\circ}$ and $49.68^{\circ}$, assigned to anorthite phase diffraction planes (223), (132) and (400) according to JCPDS 12-0301 file and at $22.16^{\circ}, 24.16^{\circ}, 42.6^{\circ}$ and $63.88^{\circ}$, attributed to albite phase diffraction planes (201), (130), (060), (4⿳亠丷厂彡1), according to JCPDS 09-0466 file. The anorthite and albite peak intensities were smaller as compared to those of mullite (Fig. 4b). The increased mullite peak intensities observed in this XRD pattern is related to enhanced mullitization behavior. The mullite peak intensities were higher in the case of S10 sample as compared to S30 and S50 samples, which implies that mullitization was enhanced by additives at this concentration. These results suggested that the mullite formation was favored by an optimum additive concentration of $10 \mathrm{wt} \%$. Above this additive concentration, XRD patterns showed the increase of the number and the intensity of anorthite and albite diffraction peaks accompanied with decreasing of those of mullite (Figs. $4 \mathrm{c}$ to $4 \mathrm{e}$ ). The increase of anorthite and albite peaks was directly linked to the increase of additive concentrations. This can be explained by the formation of the anorthite and albite phases at high temperatures by the reactions between $\mathrm{CaCO}_{3}, \mathrm{Na}_{2} \mathrm{CO}_{3}$ and kaolin according to the following reactions:

$$
\begin{aligned}
& \mathrm{Al}_{2} \mathrm{O}_{3} \cdot 2 \mathrm{SiO}_{2} \cdot 2 \mathrm{H}_{2} \mathrm{O}-2 \mathrm{H}_{2} \mathrm{O} \rightarrow \mathrm{Al}_{2} \mathrm{O}_{3} \cdot 2 \mathrm{SiO}_{2}+4 \mathrm{H}_{2} \mathrm{O} \\
& 3\left[\mathrm{Al}_{2} \mathrm{O}_{3} \cdot 2 \mathrm{SiO}_{2}\right] \rightarrow 3 \mathrm{Al}_{2} \mathrm{O}_{3} \cdot 2 \mathrm{SiO}_{2}+4 \mathrm{SiO}_{2} \\
& \mathrm{CaCO}_{3} \rightarrow \mathrm{CaO}+\mathrm{CO}_{2} \\
& {\left[3 \mathrm{Al}_{2} \mathrm{O}_{3} \cdot 2 \mathrm{SiO}_{2}\right]+3 \mathrm{CaO}+4 \mathrm{SiO}_{2} \rightarrow} \\
& 3\left[\mathrm{CaO}_{2} \mathrm{Al}_{2} \mathrm{O}_{3} \cdot 2 \mathrm{SiO}_{2}\right] \\
& \mathrm{Na}_{2} \mathrm{CO}_{3} \rightarrow \mathrm{Na}_{2} \mathrm{O}+\mathrm{CO}_{2} \\
& 2\left[3 \mathrm{Al}_{2} \mathrm{O}_{3} \cdot 2 \mathrm{SiO}_{2}\right]+6 \mathrm{Na}_{2} \mathrm{O}+11 \mathrm{SiO}_{2} \rightarrow \\
& 3\left[2 \mathrm{Na}_{2} \mathrm{O} \cdot 2 \mathrm{Al}_{2} \mathrm{O}_{3} \cdot 5 \mathrm{SiO}_{2}\right]
\end{aligned}
$$

Morphology investigation: in order to follow the microstructure changes of obtained ceramics, the SEM micrographs are illustrated in Fig. 5. It was clearly observed that the samples morphology was additive content dependent. The sample S10 was rich in needle-like whisker structure and rounded like phases, which were randomly oriented and interwoven to form a short pore network structure (Figs. 5a and 5a'). The needle-like whisker structure may be attributed to the mullite phase which is the dominant one

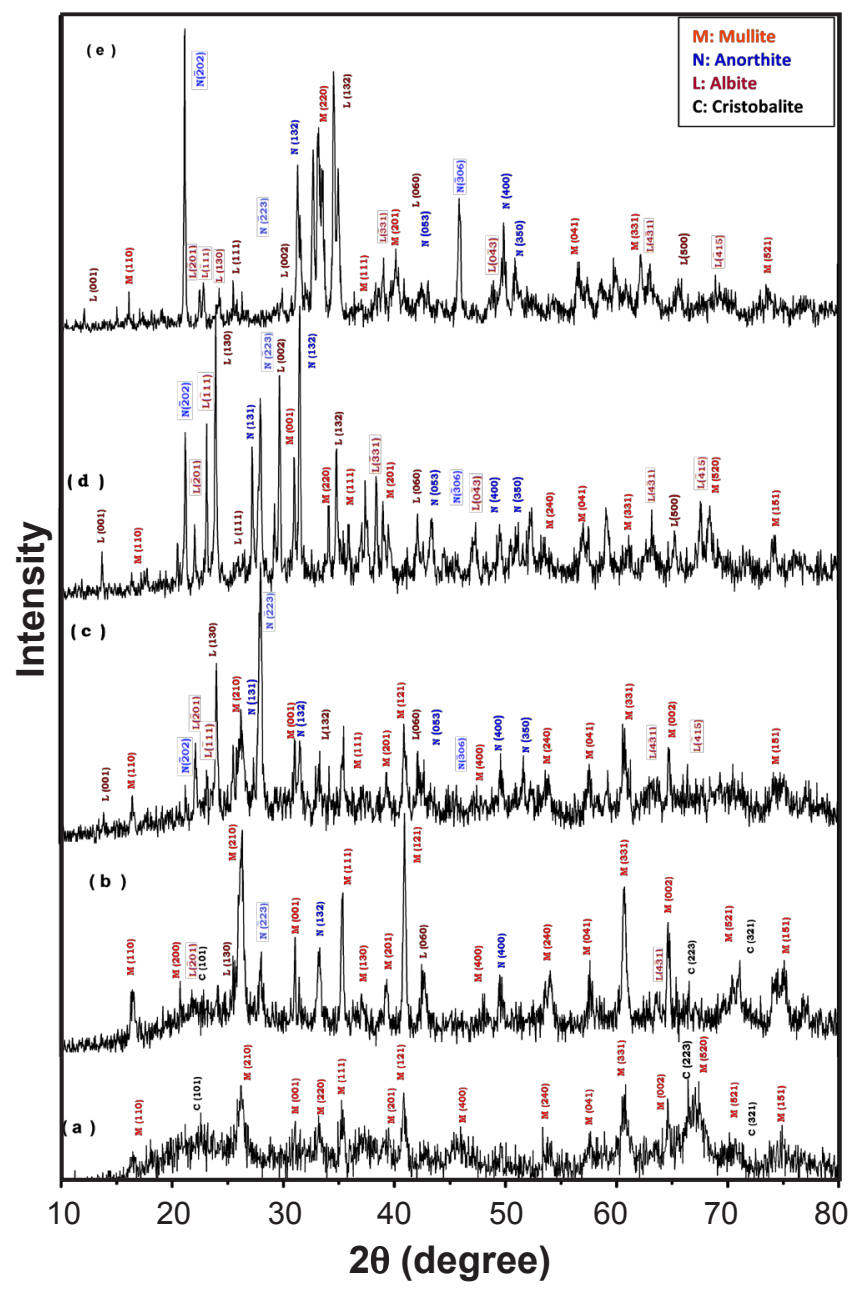

Figure 4: X-ray diffraction patterns of prepared ceramics: (a) S0, (b) S10, (c) S30, (d) S50, and (e) S70.

[Figura 4: Difratogramas de raios $X$ das cerâmicas preparadas: (a) SO, (b) S10, (c) S30, (d) S50 e (e) S70.]

as revealed by XRD results (Fig. 4b). A similar morphology was observed in kaolin combined with alumina additives to prepare porous mullite ceramic membranes [32]. As additive concentration increased, the S30 micrograph (Fig. $5 b)$ revealed the coexistence of the mullite, anorthite and albite grain morphologies. Indeed, the needle-like whisker mullite grains, the tabular crystals (stacked plates) of albite and the plate-like morphology of anorthite grains were simultaneously observed on the corresponding SEM image with high magnification (Fig. 5b'). The grains were strongly bounded together resulting in an interlocking microstructure leading to the formation of a pore network structure with irregular size and shape. In fact, the XRD results prove the presence of the mullite, albite and anorthite phases at this sample composition. For the samples S50 and S70, the absence of mullite whiskers (Figs. 5c and 5d) can be attributed to: i) the decrease of mullite proportion in the sample, as revealed by XRD results; and ii) the wrap of the whiskers between albite and anorthite particles leading to the formation of blocks. As a result, the pores have been expanded to large gaps formed by the blocks connections. 

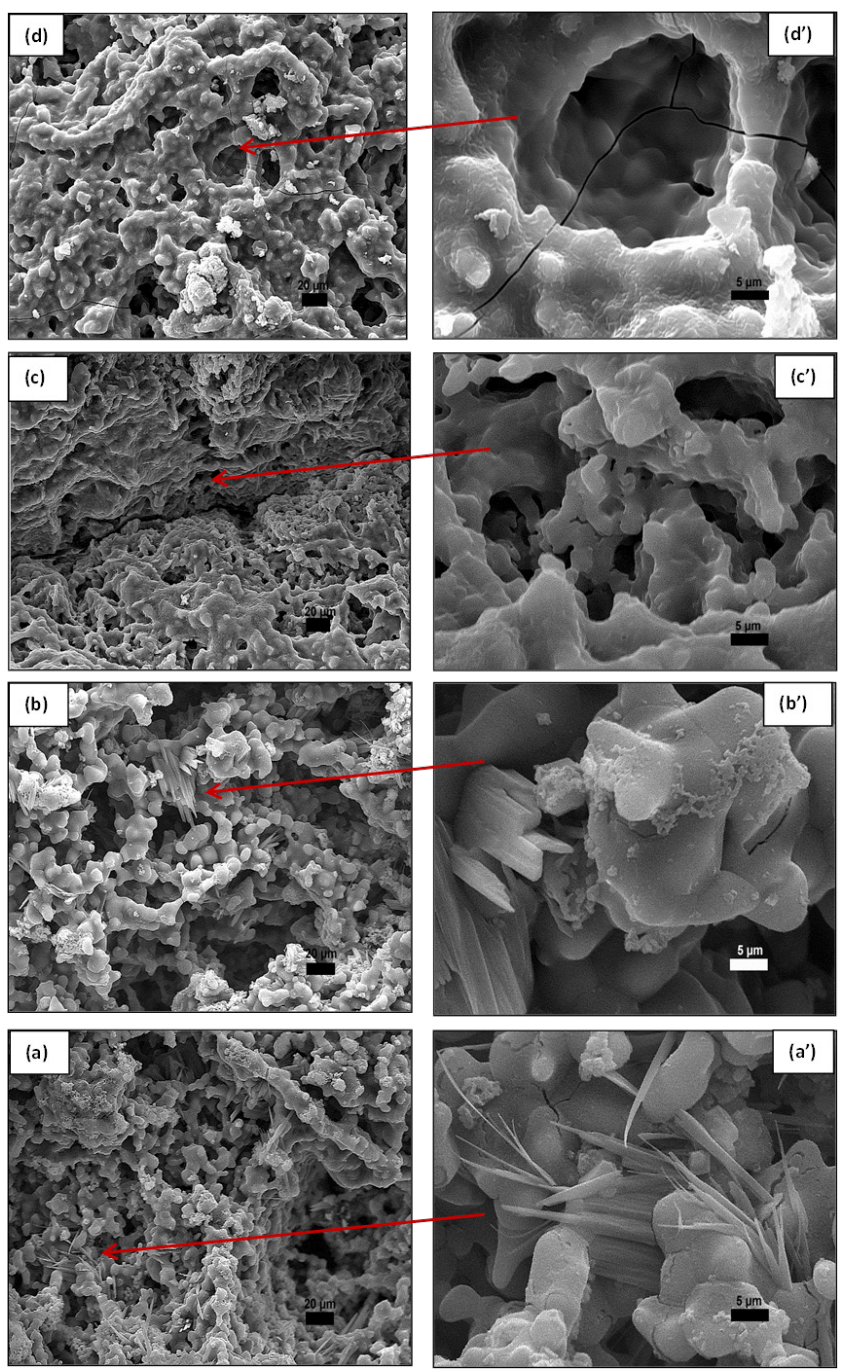

Figure 5: SEM micrographs of sintered samples: (a,a') S10, (b,b') S30, (c,c') S50, and (d,d') S70.

[Figura 5: Micrografias obtidas por microscopia eletrônica de varredura das amostras sinterizadas: (a, $\left.a^{\prime}\right)$ S10, $\left(b, b^{\prime}\right)$ S30, (c, c') S50 e (d,d') S70.]

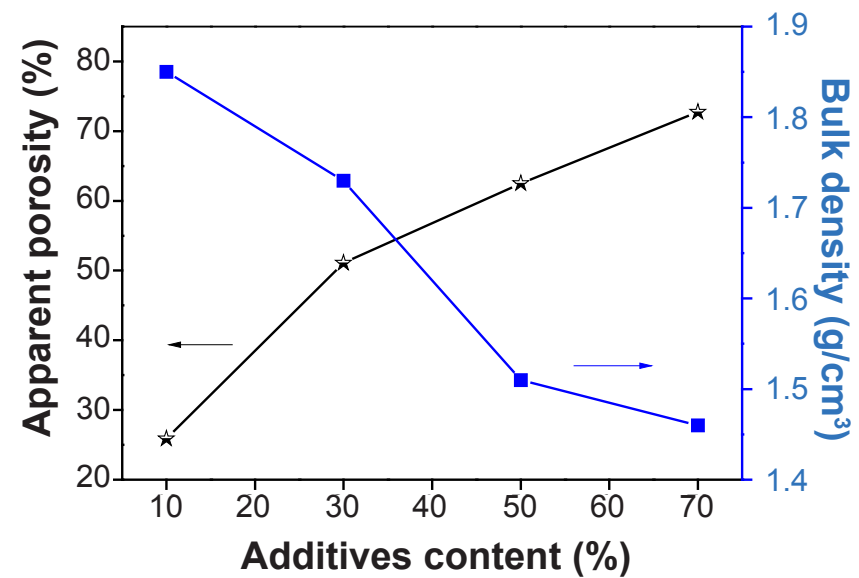

Figure 6: Apparent porosity and bulk density as function of additive content.

[Figura 6: Porosidade aparente e densidade aparente em função da fração de aditivos.]
Hence, the pore structure presented two types of pores: larger and irregular pores, and smaller and rounded pores. The high magnification SEM images showed that S50 and S70 presented a high porosity with the appearance of cracks (Figs. $5 c^{\prime}$ and $\left.5 d^{\prime}\right)$. This result was supported by the estimation of the apparent porosity and bulk density of different samples (Fig. 6). An increase of the apparent porosity values between $24.8 \%$ and $72.7 \%$ for S10 and S70, respectively, was observed. Moreover, it can be seen that the bulk density decreased from $1.85 \mathrm{~g} / \mathrm{cm}^{3}$ for S10 to $1.46 \mathrm{~g} / \mathrm{cm}^{3}$ for S70. This may be due to the release of $\mathrm{CO}_{2}$ gas formed during carbonate compound decomposition reactions favored by the increase of additive content in the samples which caused the increase of pore volume and the samples exhibited a sponge-like morphology [33].

Thermal transformation analysis: the DSC curves of obtained mixtures before heat treatment ( $\mathrm{S} 0, \mathrm{~S} 10, \mathrm{~S} 30, \mathrm{~S} 50$, S70) are presented in Fig. 7. The DSC curves exhibited four main regions: i) region $1\left(\mathrm{~T}<200{ }^{\circ} \mathrm{C}\right)$ : all samples showed an endothermic peak attributed to elimination of adsorbed and absorbed water [34]; the peak position and intensity increased with increasing additive concentration; this may be due to the presence of high percentage of absorbed water in additives and/or the high $\mathrm{pH}$ values (8-9) of additives which improved the kaolin dehydration; ii) region $2(\mathrm{~T}=200$ $820{ }^{\circ} \mathrm{C}$ ): an endothermic peak centered at $558{ }^{\circ} \mathrm{C}$ was assigned to dehydroxylation process of kaolin leading to the transformation of kaolinite to metakaolinite $\left(\mathrm{Al}_{2} \mathrm{O}_{3} .2 \mathrm{SiO}_{2}\right)$ and the loss of structural hydroxyl groups; the proposed dehydroxylation mechanism consists of the division of hydroxyl groups into $\mathrm{H}^{+}$and $\mathrm{O}^{2-}$ ions; the $\mathrm{H}^{+}$ions form water molecules with $\mathrm{OH}^{-}$groups while the $\mathrm{O}^{2-}$ ions are bonded to the newly created metakaolinite lattice [35]; it was noticed that the peak position and intensity decreased with the increase of additive concentration; this can be explained by the decrease of kaolin amount in the samples; a new endothermic peak was detected around $780{ }^{\circ} \mathrm{C}$ in S30, S50 and S70 samples which may be assigned to the decomposition reactions of carbonate (Eqs. $\mathrm{C}$ and E) [14]; iii) region $3\left(\mathrm{~T}=820-1100{ }^{\circ} \mathrm{C}\right)$ : the exothermic peak at about $995^{\circ} \mathrm{C}$ with a formation enthalpy, $\Delta \mathrm{H}$, of $-64.24 \mathrm{~J} / \mathrm{g}$ observed for $\mathrm{S} 0$ was related to the transformation of metakaolinite to mullite phase [36]; with the increase of additive concentration, both the peak position and intensity decreased progressively indicating that the mineral formation proportion decreased in all samples; iv) region 4 $\left(\mathrm{T}=1100-1500{ }^{\circ} \mathrm{C}\right)$ : for the sample $\mathrm{S} 0$, an exothermic peak was observed at $1295{ }^{\circ} \mathrm{C}$ with a stored enthalpy of about $\Delta \mathrm{H}=-21.30 \mathrm{~J} / \mathrm{g}$; this may be due to the crystallization of cristobalite [37]; S10 exhibited two exothermic peaks, the first at $1136{ }^{\circ} \mathrm{C}$ corresponding to the formation of albite phase $(\Delta \mathrm{H}=-7.29 \mathrm{~J} / \mathrm{g})$ and the second at $1325{ }^{\circ} \mathrm{C}$ corresponding to anorthite phase formation $(\Delta \mathrm{H}=-19.24 \mathrm{~J} / \mathrm{g})$; sample $\mathrm{S} 30$ exhibited two small exothermic peaks at $1194{ }^{\circ} \mathrm{C}$ attributed to the albite crystal formation $(\Delta \mathrm{H}=-4.14 \mathrm{~J} / \mathrm{g})$ and at $1376{ }^{\circ} \mathrm{C}$ $(\Delta \mathrm{H}=-2.81 \mathrm{~J} / \mathrm{g})$ corresponding to the anorthite formation; for the sample $\mathrm{S} 50$, a small exothermic peak was observed at around $1218{ }^{\circ} \mathrm{C}$ which was due to the formation of albite 


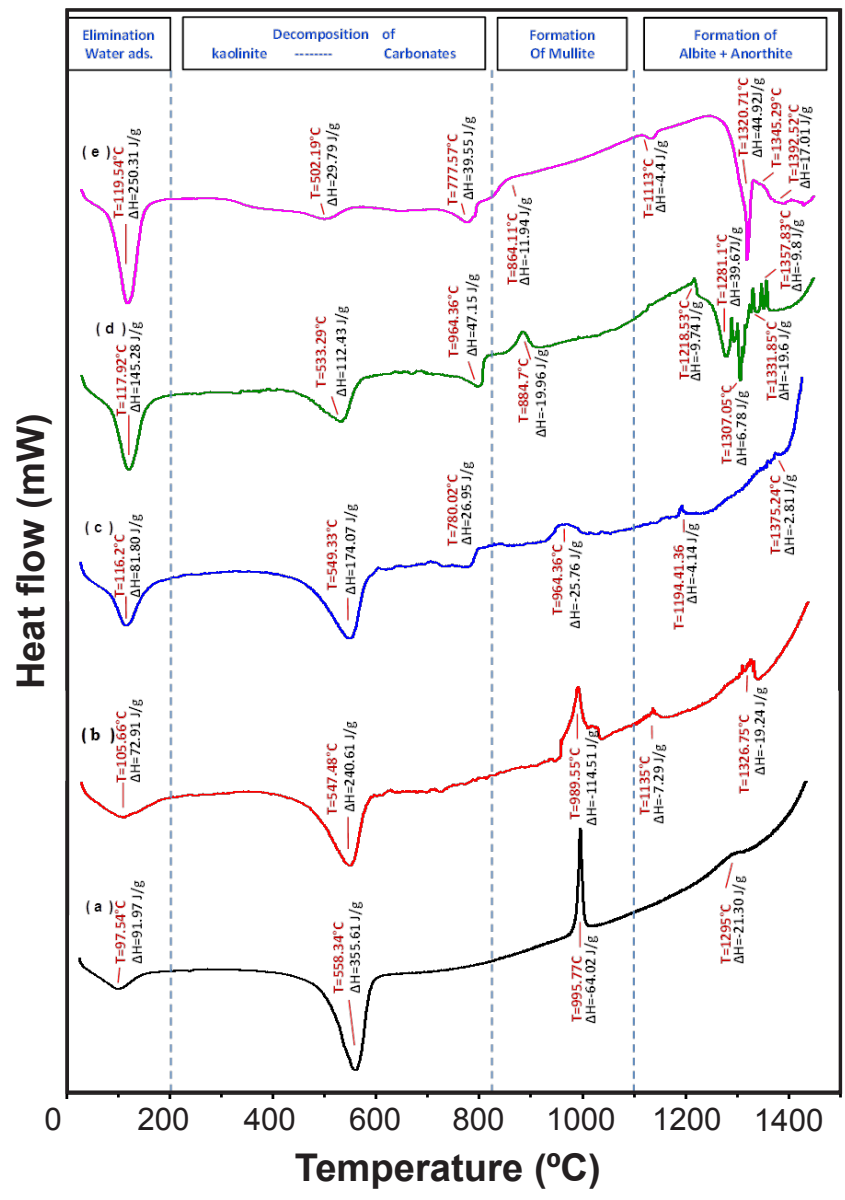

Figure 7: DSC curves of mixtures: (a) S0, (b) S10, (c) S30, (d) S50, and (e) S70.

[Figura 7: Curvas de DSC das misturas: (a) S0, (b) S10, (c) S30, (d) $S 50$ e (e) $S 70$.

phase $(\Delta \mathrm{H}=-9.74 \mathrm{~J} / \mathrm{g})$; in addition, three small exothermic peaks appeared at 1331,1348 and $1357^{\circ} \mathrm{C}$ assigned to the formation of anorthite polymorphic phases; the endothermic peaks appeared at 1280 and $1343{ }^{\circ} \mathrm{C}$ attributed, respectively, to the eutectic melts $2 \mathrm{CaO} \cdot \mathrm{Al}_{2} \mathrm{O}_{3} \cdot \mathrm{SiO}-\mathrm{CaO} \cdot \mathrm{SiO}_{2}-3 \mathrm{CaO}$. $\mathrm{SiO}_{2}$ and $\mathrm{SiO}_{2}-\mathrm{Al}_{2} \mathrm{O}_{3} \cdot \mathrm{SiO}_{2}-\mathrm{CaO} \cdot \mathrm{Al}_{2} \mathrm{O}_{3} \cdot 2 \mathrm{SiO}_{2}$ [38]; the same phenomena were observed for the sample S70; the first exothermic peak at $1113{ }^{\circ} \mathrm{C}$ corresponded to the formation of albite $(\Delta \mathrm{H}=-4.4 \mathrm{~J} / \mathrm{g})$; the endothermic peaks showed the melt points of eutectic $2 \mathrm{CaO} \cdot \mathrm{SiO}_{2}-5 \mathrm{CaO} \cdot \mathrm{Al}_{2} \mathrm{O}_{3}-3 \mathrm{CaO} \cdot \mathrm{Al}_{2} \mathrm{O}_{3}$ at $1320{ }^{\circ} \mathrm{C}$, eutectic metakaolinite $\left(2 \mathrm{SiO}_{2} \cdot \mathrm{Al}_{2} \mathrm{O}_{3}\right)$-anorthite $\left(2 \mathrm{SiO}_{2} \cdot \mathrm{Al}_{2} \mathrm{O}_{3} \cdot \mathrm{CaO}\right)$-gehlenite $\left(\mathrm{SiO}_{2} \cdot \mathrm{Al}_{2} \mathrm{O}_{3} \cdot 2 \mathrm{CaO}\right)$ at $1392{ }^{\circ} \mathrm{C}$ [39]; here in, it can be concluded that the increase of additive concentration leaded to the decrease of both formation temperature and their corresponding formation enthalpy of the existing minerals (mullite, anorthite and albite). This may be attributed to the additional energy provided by the different reactions of the additives $\left(\mathrm{Na}_{2} \mathrm{CO}_{3}\right.$ and $\left.\mathrm{CaCO}_{3}\right)$ commonly used to reduce the temperatures in solid-state reactions.

\section{CONCLUSIONS}

In this work, a novel ceramic (mullite-anorthite-albite) was prepared from natural kaolin and chemical additives
$\left(\mathrm{CaCO}_{3}\right.$ and $\left.\mathrm{Na}_{2} \mathrm{CO}_{3}\right)$ by a solid-state reaction at high temperature $\left(1200{ }^{\circ} \mathrm{C}\right)$. The $\mathrm{XRD}$ analysis showed that mullite $\left(3 \mathrm{Al}_{2} \mathrm{O}_{3} \cdot 2 \mathrm{SiO}_{2}\right)$, anorthite $\left(\mathrm{CaO} \cdot \mathrm{Al}_{2} \mathrm{O}_{3} \cdot 2 \mathrm{SiO}_{2}\right)$, and albite $\left(\mathrm{Na}_{2} \mathrm{O} \cdot \mathrm{Al}_{2} \mathrm{O}_{3} \cdot 6 \mathrm{SiO}_{2}\right)$ were the main crystalline phases present in the product. The DSC curves revealed the presence of four temperature regions related to the ceramic thermal transformation phenomena. The formation temperature and enthalpy of obtained phases were additive concentration dependent. The morphology investigations confirmed the porous texture of obtained ceramics characterized by the presence of a sponge-like structure. The optimal composition, which allowed the coexistence of the three phases (mullite, anorthite and albite), a sponge-like morphology and high porosity without cracks corresponded to $15 \mathrm{wt} \% \mathrm{CaCO}_{3}, 15$ wt $\% \mathrm{Na}_{2} \mathrm{CO}_{3}$, and $70 \mathrm{wt} \%$ kaolin.

\section{ACKNOWLEDGMENT}

This work was supported by Algerian Ministry of Higher Education and Scientific Research (CNEPRU project $\mathrm{N}^{\circ}$ A16N01UN240120150004).

\section{REFERENCES}

[1] H. Dai, X. Wang, Y. Han, X. Jiang, S. Li, J. Mater. Sci. Tech. 27 (2011) 431.

[2] J.T. Richardson, Y. Peng, D. Remue, Catal. A: General 204 (2000) 19.

[3] J. Li, H. Lin, J. Li, J. Eur. Ceram. Soc. 31 (2011) 825.

[4] S. Basu, M. Saha, S. Chatterjee, K.Kr. Mistry, Mater. Lett. 49 (2001) 29.

[5] A. Julbe, D. Farrusseng, C. Guizard, J. Membr. Sci. 181 (2001) 3 .

[6] D.M. EL-Mekkawi, M.M. Selim, J. Environ. Chem. Eng. 2 (2014) 723.

[7] H. Baccour, M. Medhioub, F. Jamoussi, T. Mhiri, J. Mater. Proc. Tech. 209 (2009) 2812.

[8] H. Celik, Appl. Clay Sci. 50 (2010) 245.

[9] M. Sakizci, B. Erdogan Alver, J. Therm. Anal. Calorim. 98 (2009) 429.

[10] P. Ptáček, T. Opravil, F. Šoukal, J. Havlica, R. Holešinský, Solid State Sci. 26 (2013) 53.

[11] N. Mu, Y. Fu, H.M. Schulz, Sedimentary Geology 331 (2016) 30 .

[12] H. Schneider, J. Schreuer, B. Hildmann, J. Eur. Ceram. Soc. 28, 2 (2008) 329.

[13] H.D. Megaw, C.J.E. Kemtster, E.W. Radoslovich, Acta Cryst. 15 (1962) 1017.

[14] A. Harabi, F. Zenikheri, B. Boudaira, F. Bouzerara, A. Guechi, L. Foughali, J. Eur. Ceram. Soc. 34 (2014) 1329.

[15] P.H. Ribbe, H.D. Megaw, W.H. Taylor, Acta Cryst. B25 (1969) 1503.

[16] J.L. Coelho, H.C.M. Lengler, S.R. Bragança, Cerâmica 62, 361 (2016) 15.

[17] M. Kazemimoghadam, T. Mohammadi, Desalination 278 (2011) 438.

[18] J.H. She, T. Ohji, Mat. Chem. Phys. 80, 3 (2003) 610. 
[19] A.V. Hmelov, Refract. Ind. Ceram. 55, 4 (2014) 341. [20] S.G. Medeiros, R.P.S. Dutra, J.P.F. Grilo, A.E. Martinelli, C.A. Paskocimas, D.A. Macedo, Cerâmica 62, 363 (2016) 266.

[21] H.P.A. Alves, R.A. Junior, L.F.A. Campos, R.P.S. Dutra, J.P.F. Grilo, F.J.A. Loureiro, D.A. Macedo, Ceram. Int. 43 (2017) 9319.

[22] X. Chen, T. Li, Q. Ren, X. Wu, H. Li, A. Dang, T. Zhao, Y. Shang, Y. Zhang, J. Alloys Compd. 700 (2017) 37.

[23] R. Sokolář, L. Vodová, S. Grygarová, I. Štubňa, P. Šín, Ceram. Int. 38 (2012) 6607.

[24] C. Li, C. Bian, Y. Han, C.A. Wang, L. An, J. Eur. Ceram. Soc. 36 (2016) 761.

[25] M. Sutcu, S. Akkurt, J. Eur. Ceram. Soc. 30 (2010) 1785.

[26] S. Zaiou, A. Harabi, E. Harabi, A. Guechi, N. Karboua, M.-T. Benhassine, S. Zouai, F. Guerfa, Cerâmica 62, 364 (2016) 317.

[27] M. Dal Bó, V. Cantavella, E. Sánchez, D. Hotza, F.A. Gilabert, J. Non-Cryst. Solids 363 (2013) 70.

[28] N.F. Cano, L.H.E. dos Santos, J.F.D. Chubaci, S. Watanabe, Spect. Chim. Acta Part A: Mol. Biomol. Spec.
137 (2015) 471.

[29] Al. Karamanov, L. Arrizza, I. Matekovits, M. Pelino, Ceram. Int. 30 (2004) 2129.

[30] M.M. Krzmanc, M. Valant, D. Suvorov, J. Eur. Ceram. Soc. 25 (2005) 2835.

[31] H.P.A. Alves. J.B. Silva. L.F.A. Campos. S.M. Torres, D.A. Macedo, Ceram. Int. 42, 16 (2016) 19086.

[32] G. Chen, X. Ge, Y. Wang, W. Xing, Y. Guo, Ceram. Int. 41 (2015) 8282.

[33] L. Simão, R.F. Caldato, M.D.M. Innocentini, O.R.K. Montedo, Ceram. Int. 41 (2015) 4782.

[34] H. Celik, Appl. Clay Sci. 50 (2010) 245.

[35] P. Ptáček, F. Frajkorová, F. Šoukal, T. Opravil, Powder Technol. 264 (2014) 439.

[36] A. Esharghawi, C. Penot, F. Nardou, Ceram. Int. 36 (2010) 231.

[37] P. Ptáček, M. Křečková, F. Šoukal, T. Opravil, J. Havlica, J. Brandštetr, Powder Technol. 232 (2012) 24.

[38] C.A. Jouenne, Traité de céramiques et des matériaux, Septima, Paris (1990).

[39] K. Traoré, T.S. Kabré, P. Blanchart, Ceram. Int. 29 (2003) 377.

(Rec. 05/05/2017, Rev. 25/06/2017, Ac. 25/07/2017) 